\title{
24. CLAY STRATIGRAPHY AT DEEP SEA DRILLING PROJECT SITES 576 AND 578, LEG 86 (WESTERN NORTH PACIFIC) ${ }^{1}$
}

\author{
Nicole Lenôtre, Bureau de Recherches Géologiques et Minières, Orléans, France \\ Hervé Chamley, Université de Lille I, Villeneuve d'Ascq, France \\ and \\ Michel Hoffert, Université de Bretagne Occidentale, Brest, France ${ }^{2}$
}

\begin{abstract}
Late Cretaceous and Cenozoic sediments deposited on the eastern and western sides of the Shatsky Rise show similar clay assemblages of chlorite, illite, mixed layers, smectite, kaolinite, and palygorskite, and a similar vertical differentiation into three units. The deep-sea pelagic red clay is dominated by terrigenous components, which suggests that diagenesis is minor in this part of the western North Pacific and that eolian supply is very important. The role of the Shatsky Rise as a submarine barrier is of minor importance. The volcanic contribution to the clay component appears very small, as in some other parts of the Pacific Ocean. Stratigraphic correlations between Sites 576 and 578, which can be made from mineralogical data, partly offset the rareness of biostratigraphic markers.
\end{abstract}

\section{INTRODUCTION}

During Deep Sea Drilling Project (DSDP) Leg 86, one site was drilled on either side of the Shatsky Rise in the northwest Pacific basin (Fig. 1). Site 576, located east of the Shatsky Rise in $6220 \mathrm{~m}$ water depth, recovered a typical northwestern Pacific pelagic "red" clay section. Holes 576 and $576 \mathrm{~B}$ penetrated about $55 \mathrm{~m}$ of pelagic red clay overlying $20 \mathrm{~m}$ of interbedded Campanian-Maestrichtian carbonate turbidites and pelagic clay before bottoming in chert at $76 \mathrm{~m}$ sub-bottom (see Site 576 chapter, this volume).

Site 578, located west of the Shatsky Rise in $6010 \mathrm{~m}$ water depth, was cored continuously to CampanianMaestrichtian chert, $176 \mathrm{~m}$ below the seafloor. Hole 578 penetrated $76 \mathrm{~m}$ of olive gray anoxic clay grading downhole to radiolarian-diatom ooze that contains at least 55 ash beds. The ooze overlies $38 \mathrm{~m}$ of yellow brown clay with locally abundant radiolarians and 19 ash beds decreasing in abundance downhole, overlying $52 \mathrm{~m}$ of dark brown homogeneous pelagic clay with rare ferromanganese micronodules and chert (see Site 578 chapter, this volume).

Detailed sedimentologic studies of Sites 576 and 578 can resolve (1) whether or not the Shatsky Rise is a barrier to sediment transport and (2) the relative roles of terrigenous autochtonous sedimentation in these typical "red" clay areas.

\section{ANALYTICAL PROCEDURES}

In our X-ray diffraction method, the samples were dissociated in water, then decarbonated in $5 N$ hydrochloric acid. Excess acid was re-

\footnotetext{
${ }^{1}$ Heath, G. R., Burckle, L. H., et al., Init. Repts. DSDP, 86: Washington (U.S. Govt. Printing Office).

2 Addresses: (Lenôtre) Bureau de Recherches Géologiques et Minières, Département Géologie Marine, B.P. 6009,45060 Orléans Cedex, France; (Chamley) Sédimentologie et Géochimie, E.R.A.764, Université de Lille 1, 59655 Villeneuve d'Ascq, Cedex, France; (Hoffert) Océanologie et Géodynamique, G.I.S. Océanographie, Université de Bretagne Occidentale, 29273 Brest, France.
}

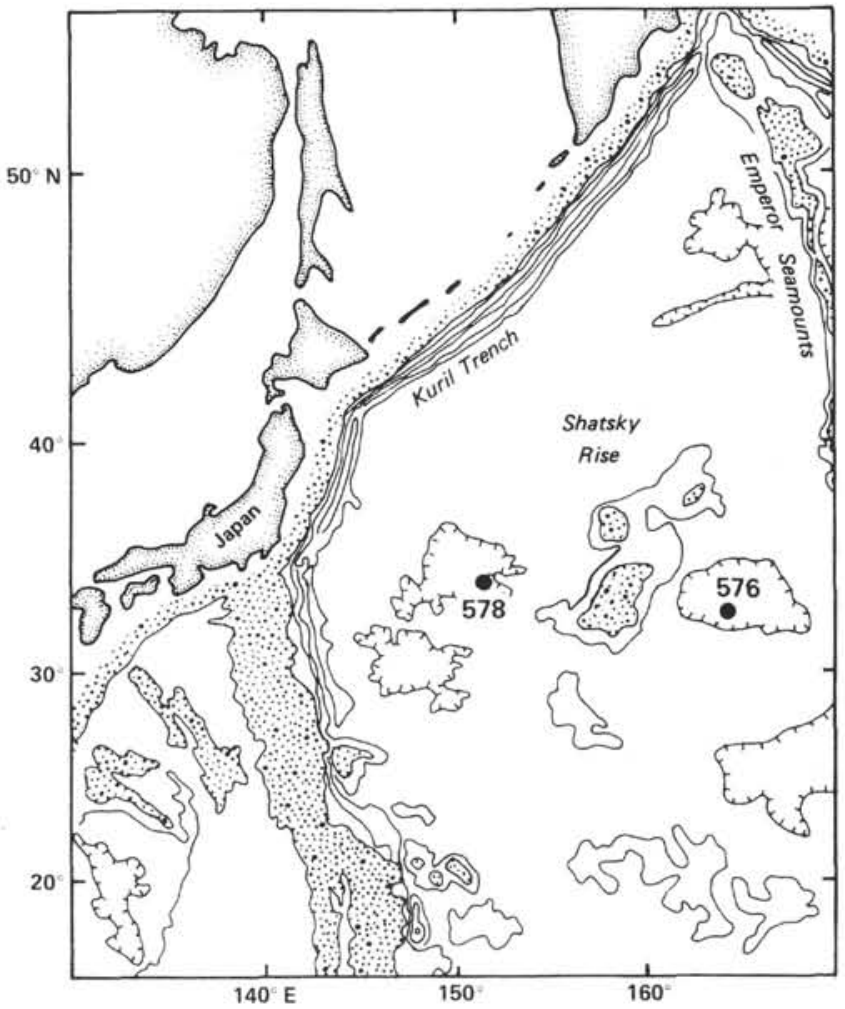

Figure 1. Location of Sites 576 and 578. Areas shallower than $4 \mathrm{~km}$ stippled, $5-\mathrm{km}$ contour plain, 6-km contour hachured.

moved by successive centrifuging. Microhomogenization effects deflocculation. Fractions smaller than $2 \mu \mathrm{m}$ were collected by decantation, using Stokes's law; then oriented pastes were made on glass slides. A Philips 1730 diffractometer (copper radiation) was used to run the Xray diffraction scans at $2^{\circ} 2 \theta / \mathrm{min}$. Three scans were carried out: (1) from $2.5^{\circ}$ to $28.5^{\circ} 2 \theta$ on natural (unglycolated) samples, (2) from $2.5^{\circ}$ to $14.5^{\circ} 2 \theta$ on glycolated samples, and (3) from $2.5^{\circ}$ to $14.5^{\circ} 2 \theta$ on samples heated for $2 \mathrm{hr}$. at $490^{\circ} \mathrm{C}$. Semiquantitative evaluations were based on peak heights and areas (Chamley, 1971). The height of illite and chlorite 001 peaks on the scan of the glycolated sample were taken 
as references. By comparison with these values, values for smectite, palygorskite, and irregular mixed-layer clays were corrected by addition of peak height, whereas values for well-crystallized kaolinite were corrected by subtraction. The relative proportions of chlorite and kaolinite were determined from the ratio of peak heights ( 3.54 and $3.58 \AA$, respectively); when this ratio was $1: 1$, the amount of chlorite was assumed to be twice that of kaolinite. Data were given in percentages, the relative error being about $\pm 5 \%$.

Electron-microscopic observations were made with a Siemens transmission microscope on less than 8- $\mu \mathrm{m}$ particles deposited on copper grids covered by a collodion film, after carbonate removal and physical deflocculation.

The geochemical procedure was as follows: the samples were dried at $105^{\circ} \mathrm{C}$, then crushed and homogenized. Samples of $0.2 \mathrm{~g}$ were subjected to alkaline fusion, solubilized by $\mathrm{HCl}$, and diluted to $100 \mathrm{ml}$; $0.2 \mathrm{~g}$ were then subjected to fluoronitric treatment in a bomb at $150^{\circ} \mathrm{C}$ and 50 bars for $\mathrm{SiO}_{2}$ and $\mathrm{Al}_{2} \mathrm{O}_{3}$ determination. Also, $1 \mathrm{~g}$ was submitted to fluoroperchloric treatment, then solubilized by $\mathrm{HCl}$ and diluted to $100 \mathrm{ml}$. The dilutions were used for colorimetric analysis of $\mathrm{TiO}_{2}$ and $\mathrm{P}_{2} \mathrm{O}_{5}$ and spectrophotometric analysis of other major and trace elements by atomic absorption in flame, with a type 5000 Perkin Elmer automatized spectrophotometer.

\section{RESULTS}

\section{Smear Slide Data}

Smear slides analyses have been carried out on each sample (selected results are shown in Table 1). Most sediments contain large amounts of clay-sized particles that are dominated by clay minerals. The sand fraction is significant in the late Pleistocene only (a few percent of quartz, feldspars, and heavy minerals). The silt fraction is generally not important and consists chiefly of siliceous biogenic debris (mainly diatoms). Nannofossils are absent, except in the Latest Cretaceous calcareous oozes, sometimes as graded beds. Volcanic glass and palagonite, as well as micronodules and opaque minerals, are dispersed in small amounts $(0-10 \%)$ throughout the sedimentary column. Phillipsite occurs rarely, except in Cores 576-4 and 5 (up to 15\%) and Sections 576B-3-6 and 4-6, and 578-17-1 and 17-3.

\section{Nature of Clay Minerals}

The clay assemblage identified in sediments from Sites 576 and 578 includes a fairly large range of minerals (Figs. 2 and 3). Well-crystallized illite (5-45\% of clay minerals) and medium-crystallized smectites (15-90\%) are the most abundant phases. They are accompanied by medium-crystallized chlorite (traces to $25 \%$ ) and kaolinite (traces to 10\%) and by noticeable amounts (traces to $30 \%$ ) of irregular mixed-layer minerals (chiefly of chlorite-smectite and illite-smectite types). Palygorskite (traces to $30 \%$ ) is easily recognizable on electron micrographs as abundant fibers, broken or whole (Plates 1 and 2). Associate minerals in the clay fraction consist of ubiquitous quartz, frequent feldspars, and opal CT.

\section{Stratigraphic Distribution}

Except for the palygorskite, the clay minerals identified occur throughout the stratigraphic column, extending from Late Cretaceous to latest Pleistocene. Three major mineralogical units can be distinguished (Figs. 2-4). The upper unit is characterized by comparable amounts of illite and smectite, and smaller amounts of chlorite, irregular mixed layers and kaolinite (Hole 576, Cores 15; Hole 576B, Cores 1-4; Hole 578, Cores 1-13). Separation between the upper unit and the middle unit is well marked by a sudden change in the proportions of clay minerals. The middle unit is characterized by high amounts of smectite and often of quartz, small amounts of palygorskite, and relatively low amounts of other clay minerals (Hole 576, Core 6 to Section 8-3; Hole $576 \mathrm{~B}$, Core 5 to Section 6-5; Hole 578, Cores 14-20). The lowest unit corresponds to the Late Cretaceous sediments recovered at Holes 576 (Section 8-3) and 576B (Sections 6-5 to 8-3) and is characterized by fairly abundant palygorskite (up to $30 \%$ ) and abundant smectite. There is no relationship between the clay mineralogy and the lithological units described in the site chapters (this volume). The clay assemblages do not change when the abundance of clay, volcanic glass, zeolites, nannofossils, or biogenic silica varies (Table 1). The upper mineralogical unit is fairly homogeneous, the relative abundance of each species varying by about 5 to $10 \%$ only. The middle mineralogical unit beneath the welldated Neogene sediments shows important quantitative variations of the different species, especially illite and smectite. Palygorskite forms less than $5 \%$ of these dark brown pelagic clays and can be clearly identified by electron microscopy only. Palygorskite appears in increased amounts on the X-ray diagrams corresponding to the Site 576 Maestrichtian-Campanian carbonates and pelagic clays (lowest unit).

\section{Clay Morphology}

Three major morphological facies can be identified from transmission electron microscopic observations. (1) The first facies is restricted to the upper part of the drill holes (Neogene to Quaternary pelagic clay and radiolarian-diatom ooze) and is characterized by abundant wellshaped and rather broad sheets, mainly of illite and chlorite (Plate 1, Figs. 1, 2). Illite and chlorite are accompanied by variable amounts of fleecy and small particles (smectite and irregular mixed layers) and a few kaolinite hexagons. Isolated fibers of palygorskite, not identifiable on X-ray diffractograms, are sparse in all the levels. More or less dissolved diatom and radiolarian debris is frequently present, and corresponds to the opal recognized by X-ray diffraction. (2) The second facies occurs chiefly in the lower part of the sedimentary columns (brown pelagic clay and nannofossil ooze) and is distinguished by fairly abundant to abundant palygorskite, which increases downward (Plate 1, Figs. 3, 4; Plate 2, Figs. 1, 2). Associated with the palygorskite in this facies are smectite, variable amounts of illite, chlorite, and kaolinite, and some strongly dissolved siliceous debris. The palygorskite occurs as well-shaped but often broken fibers, either isolated or grouped into small bundles. The abundance of the fibrous clays on electron micrographs appears higher than on X-ray diffractograms, especially in Sample 576B-8-3, $82 \mathrm{~cm}$ where these minerals occupy nearly $50 \%$ of the total clay surface. (3) The third morphological facies consists of very abundant smectite (up to $80 \%$ ) and corresponds to the brown pelagic clay in the lower, barren part of the drilled sections. Smectite 
Table 1. Clay mineralogy and smear slide data (\%) of selected samples from Sites 576 and 578.

\begin{tabular}{|c|c|c|c|c|c|c|c|c|c|c|c|c|c|c|c|c|c|c|}
\hline \multirow[b]{3}{*}{$\begin{array}{c}\text { Sample } \\
\text { (interval in cm) }\end{array}$} & \multicolumn{12}{|c|}{ Smear slide } & \multirow{2}{*}{\multicolumn{6}{|c|}{$\begin{array}{c}\mathrm{X} \text {-ray diffractograms } \\
\text { Clay mineralogy }\end{array}$}} \\
\hline & \multicolumn{3}{|c|}{ Grain size } & \multicolumn{9}{|c|}{ Bulk petrography } & & & & & & \\
\hline & Sand & Silt & Clay & $\begin{array}{c}\text { Clay } \\
\text { minerals }\end{array}$ & Quartz & Zeolites & $\begin{array}{l}\text { Other } \\
\text { minerals }\end{array}$ & $\begin{array}{l}\text { Volcanic } \\
\text { glass }\end{array}$ & Palagonite & Opaques & $\begin{array}{l}\text { Micro- } \\
\text { nodules }\end{array}$ & $\begin{array}{l}\text { Siliceous } \\
\text { debris }\end{array}$ & Chlorite & Illite & $\begin{array}{l}\text { Mixed } \\
\text { layers }\end{array}$ & Smectite & Kaolinite & $\begin{array}{l}\text { Palygor- } \\
\text { skite }\end{array}$ \\
\hline \multicolumn{19}{|l|}{ Hole 576} \\
\hline $1-1,26-28$ & 1 & 39 & 60 & 70 & 20 & - & 2 & 2 & 2 & 1 & 1 & 3 & 25 & 40 & 15 & 15 & 5 & - \\
\hline $2-3,130-132$ & 0 & 5 & 95 & 90 & 5 & - & tr & 1 & 1 & tr & 2 & 1 & 5 & 35 & 15 & 35 & 10 & - \\
\hline $6-3,20-22$ & 1 & 4 & 95 & 95 & tr & 5 & - & - & - & - & - & - & 5 & 20 & 5 & 65 & 5 & - \\
\hline \multicolumn{19}{|l|}{ Hole 576B } \\
\hline $1-6,10-13$ & 7 & 13 & 80 & 75 & 15 & - & - & 5 & 2 & - & 1 & 2 & 10 & 35 & 15 & 35 & 5 & - \\
\hline $5-2,100-103$ & 1 & 5 & 94 & 94 & 1 & - & tr & 1 & - & 2 & 2 & - & 5 & 10 & 5 & 80 & tr & tr \\
\hline $8-3,30-33$ & 1 & 8 & 91 & 91 & 1 & - & tr & 1 & - & 2 & 5 & - & tr & 10 & 10 & 55 & tr & 25 \\
\hline \multicolumn{19}{|l|}{ Hole 578} \\
\hline $2-3,20-22$ & 15 & 40 & 45 & 44 & 20 & - & 1 & 10 & - & - & - & 25 & 10 & 25 & 15 & 40 & 10 & - \\
\hline $5-2,78-80$ & 3 & 17 & 80 & 80 & 3 & - & 1 & 1 & 2 & - & - & 13 & 15 & 35 & 15 & 25 & 10 & - \\
\hline $6-6,78-80$ & 10 & 25 & 65 & 65 & 3 & - & tr & 22 & - & - & - & 10 & 15 & 35 & 20 & 25 & 5 & - \\
\hline $11-2,30-32$ & 2 & 20 & 78 & 78 & 3 & - & tr & tr & tr & 5 & - & 14 & 5 & 30 & 15 & 40 & 10 & - \\
\hline $15-6,33-35$ & 0 & 7 & 93 & 93 & 2 & - & tr & tr & 1 & 3 & 1 & - & tr & 10 & 5 & 80 & 5 & - \\
\hline $16-6,10-12$ & 0 & 5 & 95 & 93 & 2 & - & tr & tr & 1 & 3 & 1 & - & tr & 10 & 5 & 80 & 5 & tr \\
\hline $18-1,56-58$ & 0 & 5 & 95 & 81 & 1 & - & tr & tr & tr & 15 & 3 & tr & 5 & 15 & tr & 75 & 5 & - \\
\hline
\end{tabular}

Note: $\operatorname{tr}=$ trace, $-=$ not present. 


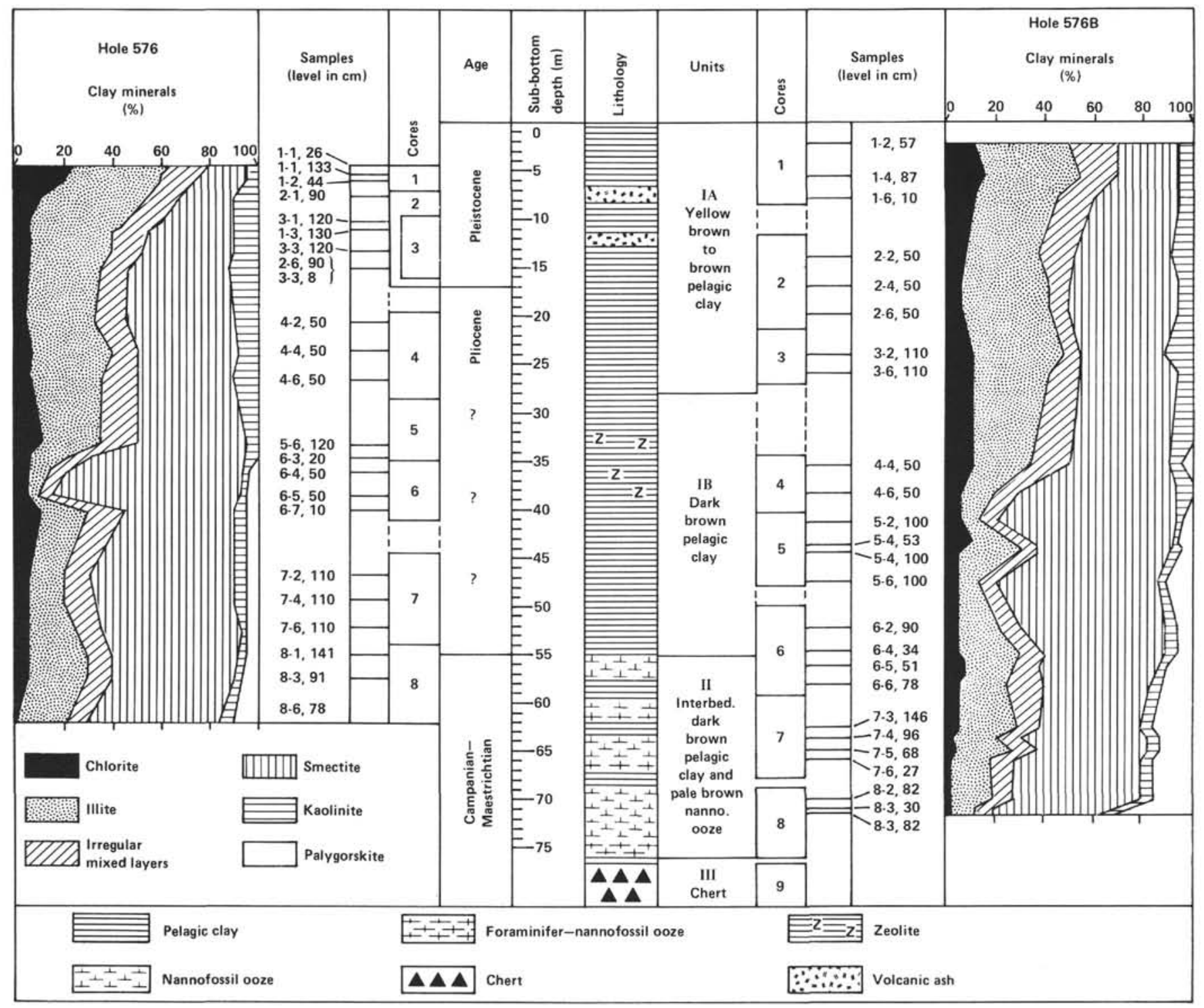

Figure 2. Lithology and clay mineralogy of Site 576 plotted versus adjusted sub-bottom depth. Tables used to compute adjusted depths are given in the Site 576 chapter (this volume).

typically occurs as cloudy and fleecy particles of variable size and is accompanied by small amounts of illite, palygorskite', and other clay minerals (Plate 2, Figs. 3, 4).

All the facies identified and all the levels studied are characterized by the total morphological independence of the different clay minerals. In particular, smectite does not show any transition from fleecy to lathed particles, and palygorskite fibers or bundles are completely isolated and dispersed among the other minerals.

\section{Comparison between Sites 576 and 578}

In addition to the similarities in the clay stratigraphy described above, the percentages of the different clay species at the two drilling sites are similar (Figs. 2 and 3 ). There are no major differences in the relative abundances of chlorite, illite, irregular mixed layers, smectite, and kaolinite on the eastern and the western sides of the Shatsky Rise. Only three minor differences can be noticed. (1) The relative abundances of illite and chlo- rite tend to increase slightly, and of smectite to decrease, toward the top of the Pleistocene sediments, east of the Shatsky Rise (Holes 576 and 576B). (2) Palygorskite is significantly more abundant in the lowest part of Hole 576B (Cores 6-8), in sediments of Campanian-Maestrichtian age that were only poorly recovered at Site 578 (Core 20). (3) Variations in the abundance of illite in the lower mineralogical zone are greater at Site 578 (e.g., Samples 578-18-4, $86 \mathrm{~cm}$ and $56 \mathrm{~cm}, 578-17-3,36 \mathrm{~cm}$, and $578-16-2,10 \mathrm{~cm})$ than at Site 576 .

\section{DISCUSSION}

\section{Origin of Clay Minerals}

The large number of clay species, the abundance of minerals typically derived from land masses (illite, irregular mixed layers, kaolinite, quartz), the parallel variations of illite and chlorite, the medium crystallinity of smectite, the absence of continuous mineralogical evo- 


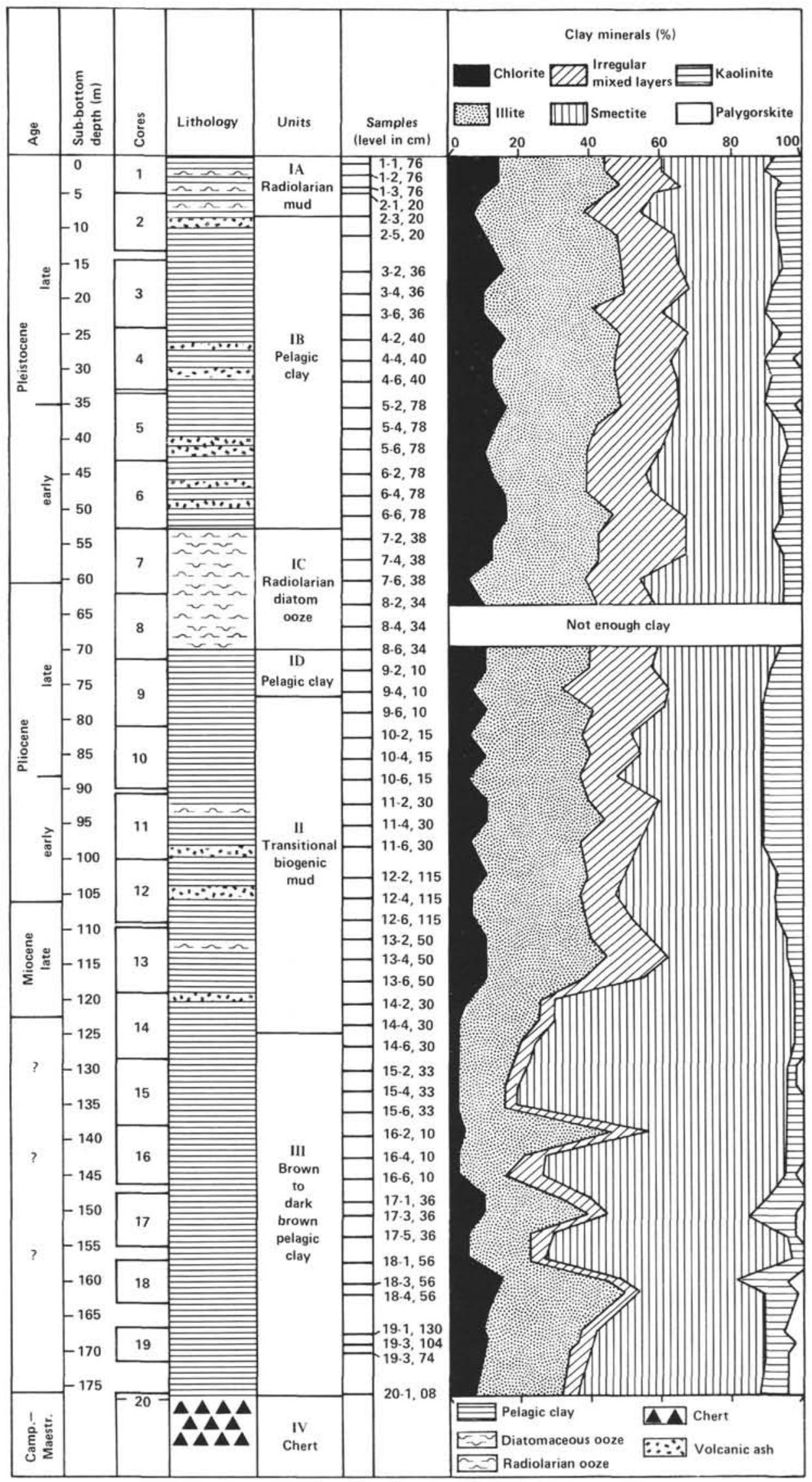

Figure 3. Lithology and clay mineralogy of Site 578. 


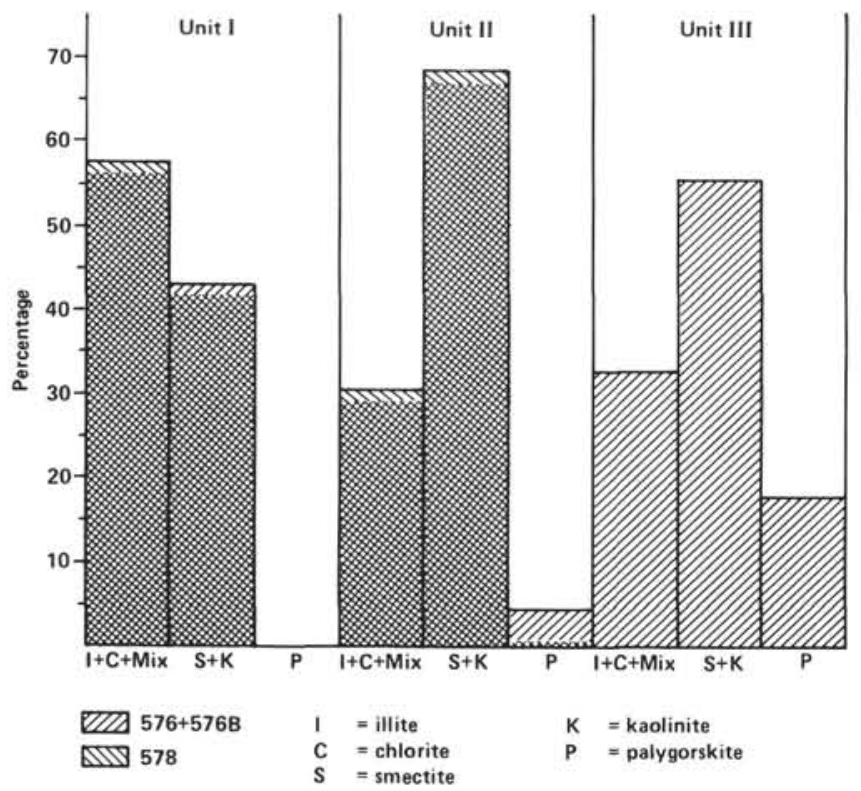

Figure 4. Comparison of clay stratigraphy in Sites 576 and 578. Results are averages of all sample compositions from each unit. Amounts of smectite and palygorskite are individualized because they vary a lot from one unit to another.

lution with increasing depth of burial, the lack of relationships between clay assemblages, lithology, and associated minerals such as zeolites or micronodules (see smear slide data in site chapters), and the morphological independence of each clay species from the others, clearly point to the importance of detrital supply to Sites 576 and 578 during the Cenozoic. Such a result is in agreement with the data of Hein et al. (1975) and Leinen and Heath (1981), who have shown the importance of detrital minerals in North Pacific sediments, especially during the past $25 \mathrm{~m}$.y. The clay assemblages identified at Sites 576 and 578 are similar to those encountered farther west in the North Pacific (Legs 57, 58, and 87), where the Neogene clays are chiefly derived from the erosion of rocks and soils in Japan and Eastern Asia (Chamley, 1981; Chamley et al., in press). The main difference at Sites 576 and 578 is the larger amount of illite, which is a typical detrital mineral that is more abundant at the more northern location of the Leg 86 drill sites (Griffin et al., 1968). Clay minerals appear to be transported from Asia by marine currents, especially the prolongation of the Kuroshio and Oyashio currents and by atmospheric circulation (Leinen and Heath, 1981).

The importance of detrital supply in the northwestern Pacific is a result of the relative proximity of the Asiatic land mass. The fairly high sedimentation rates $\left(\sim 3 \mathrm{~cm} / 10^{3}\right.$ yr. during the Pleistocene at Site $578 ; 1 \mathrm{~cm} /$ $10^{3} \mathrm{yr}$. at Site 576) inhibit reactions between aluminosilicates and seawater and diminish the possibility of in situ clay genesis. This situation contrasts with other parts of the Pacific, especially in the central eastern zone, where very low sedimentation rates and the absence of significant detrital supply allow the autochtonous formation of large amounts of smectite (Hoffert, 1980).

\section{Volcanic Influence on the Clay Composition}

The relative abundance and good crystallinity of smectite, partly associated with significant amounts of palygorskite, in the lower part of the sedimentary columns at Sites 576 and 578 could result from the alteration of volcanic materials or from increased volcanohydrothermal activity during the early Cenozoic and the Latest Cretaceous. Such a possibility is not supported by the facts. Electron micrographs do not show the large smectite laths or tufts typically developed from the alteration of volcanic lava, ash, or glass (e.g., Chamley, 1981). Palygorskite and smectite are not developed in nodules, concretions, or specific levels and are completely dispersed among the detrital minerals (Plates 1 and 2). Moreover, there is no relationship between the abundance of smectite or palygorskite and the presence or abundance of morphologically distinct volcanic particles, zeolites such as phillipsite, or palagonite (Table 1). Similarly, the smectite abundance and morphology are not correlated with the presence or abundance of opaque minerals, micronodules, iron oxides, or siliceous debris. All of these observations argue against autochtonous clay genesis due to volcanism or in situ conditions. If diagenetic processes occur in the Shatsky Rise area, they have had little impact on the clay mineralogical budget since the end of the Cretaceous. This is analogous to the situation in the Atlantic Ocean which also has fairly high sedimentation rates (Chamley, 1979).

\section{Influence of the Shatsky Rise on Clay Sedimentation}

A significant finding from the mineralogical study is the absence of differences across the Shatsky Rise. The types and proportions of clay minerals identified are the same and show similar proportions on the eastern (Site 576) and on the western (Site 578) sides of the Rise. Palygorskite is more abundant in the lower part of Site 576B (from Cores 576-8 and 576B-6 downward) than at the base of Site 578 (Figs. 2 and 3), but this is probably due to a slight difference in age: Hole 578 bottomed in late Maestrichtian deposits, whereas Holes 576 and 576B penetrated into Campanian-Maestrichtian sediments.

The first consequence of the mineralogical similarity between the two sites is that the Shatsky Rise did not act as a significant barrier to the detrital supply from Asiatic land masses. This is especially true for minerals of unequivocal terrigenous origin such as illite, chlorite, mixed layers, and kaolinite. The transport of land-derived minerals has occurred either by surficial and intermediate water masses little affected by submarine barriers, or by air masses as shown by Bonatti and Arrhenius (1965), Windom (1975), Leinen and Heath (1981), Rea and Janecek $(1981,1982)$. The Shatsky Rise may have limited the amounts, but not the nature, of detrital materials issued from Asia. This is suggested by the lower sedimentation rates at Site 576 than at Site 578 . Such a decreased terrigenous supply could also result solely from the increased distance of the source land masses.

The second consequence of the homogeneous influence of the land supply across the whole Shatsky Rise 
area is that the clay successions identified at Sites $\mathbf{5 7 6}$ and 578 can be used for stratigraphic correlations (Figs. 2, 3, and 4). Mineralogical correlations between the two sites are particularly useful when the sediments are devoid of common microfossils, as is the case for the brown to dark brown pelagic clays located below the well-dated Neogene sediments. The general stratigraphic correlations based on clay mineralogical data are summarized in Table 2. More precise stratigraphic correlations might be possible but they would necessitate more dense sampling. For example, the increase in illite and chlorite in Samples 576-6-7, 576B-5-4, and 578-16-2 (Figs. 2 and 3) could be an identifying marker. The inverse variations of the illite group (illite, chlorite, irregular mixed layers), and of the smectite during the Neogene and the Quaternary at Site 578 (Fig. 3), probably reflect climatic variations on land (soils development) and in the sea (location and intensity of currents).

The influence of the Shatsky Rise on clay sedimentation during the Latest Cretaceous and the early Cenozoic remains questionable. The sources of the large amounts of smectite and, locally, of palygorskite in the sediments could be Asia, where these minerals could have formed massively in soils and perimarine basins of the world during the warm and humidity-contrasted climate of this geologic period ( e.g., Millot, 1964; Chamley, 1979). Eolian transport is possible, given the parallel increases of smectite, palygorskite, and quartz often observed in sediments from Sites 576 and 578 (see also Leinen and Heath, 1981; and Leinen, this volume). Alternatively, the Shatsky Rise itself could have been a source if this volcanic area was emergent and exposed to weathering and erosion during the early Cenozoic. The large oscillations in the abundance of illite, chlorite, and kaolinite, which are particularly well recorded in pre-Miocene sediments at Site 578, could perhaps record major stages of subsidence of the rise toward its present position. There is, however, no hard evidence to support the hypothesis of an emergence of the Shatsky Rise: Late Cretaceous and Cenozoic sequences sampled by DSDP Legs 6 and 32 consist of pelagic nannofossil ooze and some

Table 2. Main stratigraphic correlations between Sites 576 and 578 , from clay mineralogical data.

\begin{tabular}{cccc}
\hline \multirow{2}{*}{$\begin{array}{c}\text { Clay mineralogical units } \\
\text { (significant minerals) }\end{array}$} & \multicolumn{3}{c}{ Unit depth (Core-Section) } \\
\cline { 2 - 4 } & Hole 576 & Hole 576B & Hole 578 \\
\hline $\begin{array}{c}\text { I } \\
\text { (chlorite, illite, mixed layers) } \\
\text { II } \\
\text { (smectite) }\end{array}$ & $1-1$ to $5-6$ & $1-1$ to $4-4$ & $1-1$ to 13-6 \\
$\begin{array}{c}\text { III } \\
\text { (palygorkite, smectite) }\end{array}$ & $6-3$ to $8-1$ & $4-6$ to $6-4$ & $14-2$ to 20-1 \\
\hline
\end{tabular}

Note: $-=$ not reached. zeolite clay (Fisher et al., 1971; Larson, Moberly, et al., 1975), but no minerals derived from subaerial weathering of volcanic rocks comparable to those recognized in the Emperor Seamount area (Karpoff, 1980).

\section{ACKNOWLEDGMENTS}

We are grateful to the Leg 86 shipboard party for helpful sampling and stimulating discussions, and to M. Bocquet, J. Carpentier, F. Dujardin, and P. Decourt for efficient technical assistance. This manuscript was improved by the helpful reviews of Margaret Leinen and Jane Schoonmaker. The financial support of ATP GGO 1983 (CNRS) and BRGM (France) is gratefully acknowledged.

\section{REFERENCES}

Bonatti, W. P., and Arrhenius, G., 1975. Eolian sedimentation in the Pacific off northern Mexico. Mar. Geol., 3:337-348.

Chamley, H., 1971. Recherches sur la sédimentation argileuse en Méditerranée. Sci. Geol. Mem., Strasbourg (France), 35:1-215. , 1979. North Atlantic clay sedimentation and paleoenvironment since the Late Jurassic. In Talwani, M., Hay, W., Ryan, W. B. F. (Eds.), Deep Drilling Res. Atlantic Ocean: Continental Margins and Paleoenvironment, Maurice Ewing Ser. (Am. Geophys. Un.), 3:342-361.

1981. Clay sedimentation and paleoenvironment in the Shikoku Basin since the middle Miocene (Deep Sea Drilling Project Leg 58, North Phillippine Sea). In Klein, G. deV., Kobayashi, K., et al., Init. Repts. DSDP, 58: Washington (U.S. Govt. Printing Office), 669-681.

Chamley, H., Cadet, J.-P., and Charvet, J., in press. Paleoenvironmental significance of Pacific clay assemblages off the Japan since the Miocene. In Kagami, H., Karig, D. E., Coulbourn, W. T., et al., Init. Repts. DSDP, 87: Washington (U.S. Govt. Printing Office).

Fisher, A. G., Heezen, B. C., et al., 1971. Init. Repts. DSDP, 6: Washington (U.S. Govt. Printing Office).

Griffin, J. J., Windom, H., and Goldberg, E. D., 1968. The distribution of clay minerals in the World Ocean. Deep-Sea Res., 15: 433-459.

Hein, J. R., Schall, D. W., and Gutmacher, C. E., 1975. Neogene clay minerals of the far NW Pacific and southern Bering Sea: sedimentation and diagenesis. Proc. Int. Clay Conf., 1975, pp. 71-80.

Hoffert, M., 1980. Les "Argiles rouges des grands fonds" dans le Pacifique Centre-Est. Authigenèse, transport, diagenèse. Sci. Geol. Mem., 61:1-231.

Karpoff, A. M., 1980. The claystone layer between two basalt flows in Hole 432A: an argument for the emergence of Nintoku Seamount. In Jackson, E. D., Koizumi, I., et al., Init. Repts. DSDP, 55: Washington (U.S. Govt. Printing Office), 707-711.

Larson, R. L., Moberly, R., et al., 1975. Init. Repts. DSDP, 32: Washington (U.S. Govt. Printing Office).

Leinen, M., and Heath, G. R., 1981. Sedimentary indicators of atmospheric activity in the Northern Hemisphere during the Cenozoic. Palaeogeogr. Paleoclimatol. Paleoecol., 36:1-21.

Millot, G., 1964. Géologie des Argiles: Paris (Masson).

Rea, D. K., Janecek, T. R., 1981. Late Cretaceous history of eolian deposition in the mid-Pacific mountains, central north Pacific Ocean. Paleogeogr., Paleoclimatol., Paleoecol., 36(1/2):55-67. 1982. Late Cenozoic changes in atmospheric circulation deduced from north Pacific eolian sediments. Mar. Geol., 49:149-167.

Windom, H. L., 1975. Eolian contributions to marine sediments. $J$. Sediment. Petrol., 45:520-529.

Date of Initial Receipt: 6 December 1983

Date of Acceptance: 2 October 1984 

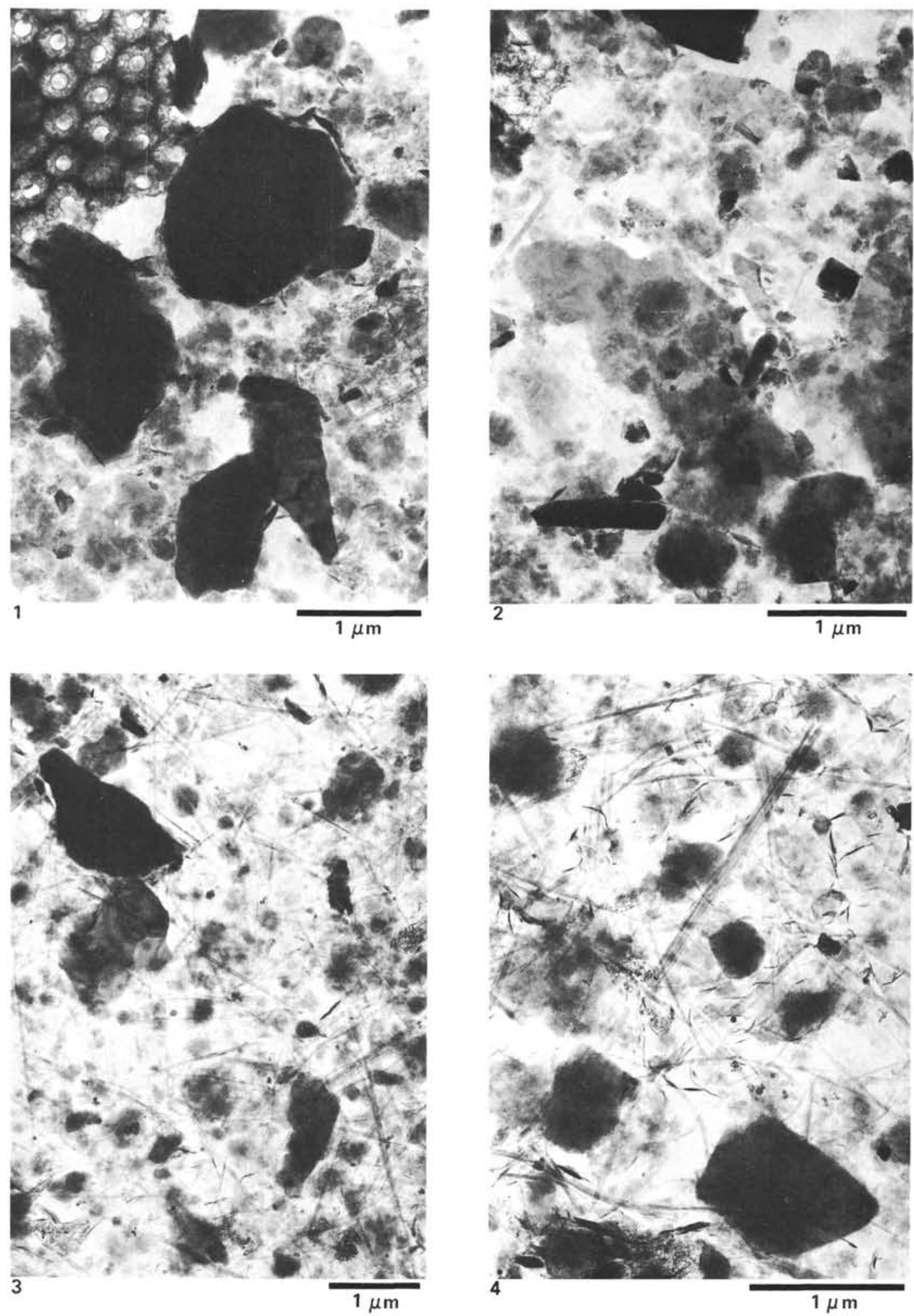

Plate 1. Electron micrographs-transmission electron microscopy. 1,2. Illite and chlorite-rich assemblage. Sample 576-1-1, 135 cm, yellowish brown to brown pelagic clay. Abundant well-shaped illite and chlorite sheets, small fleecy smectite particles, rare hexagonal kaolinite and fibers of palygorskite. Siliceous biogenic debris. 3,4. Assemblage with fairly abundant palygorskite. Sample 576-8-6, $78 \mathrm{~cm}$, Upper Cretaceous, dark brown pelagic clay. Isolated palygorskite fibers or bundles, sometimes broken. Illite, chlorite, and smectite. Strongly dissolved siliceous debris. 

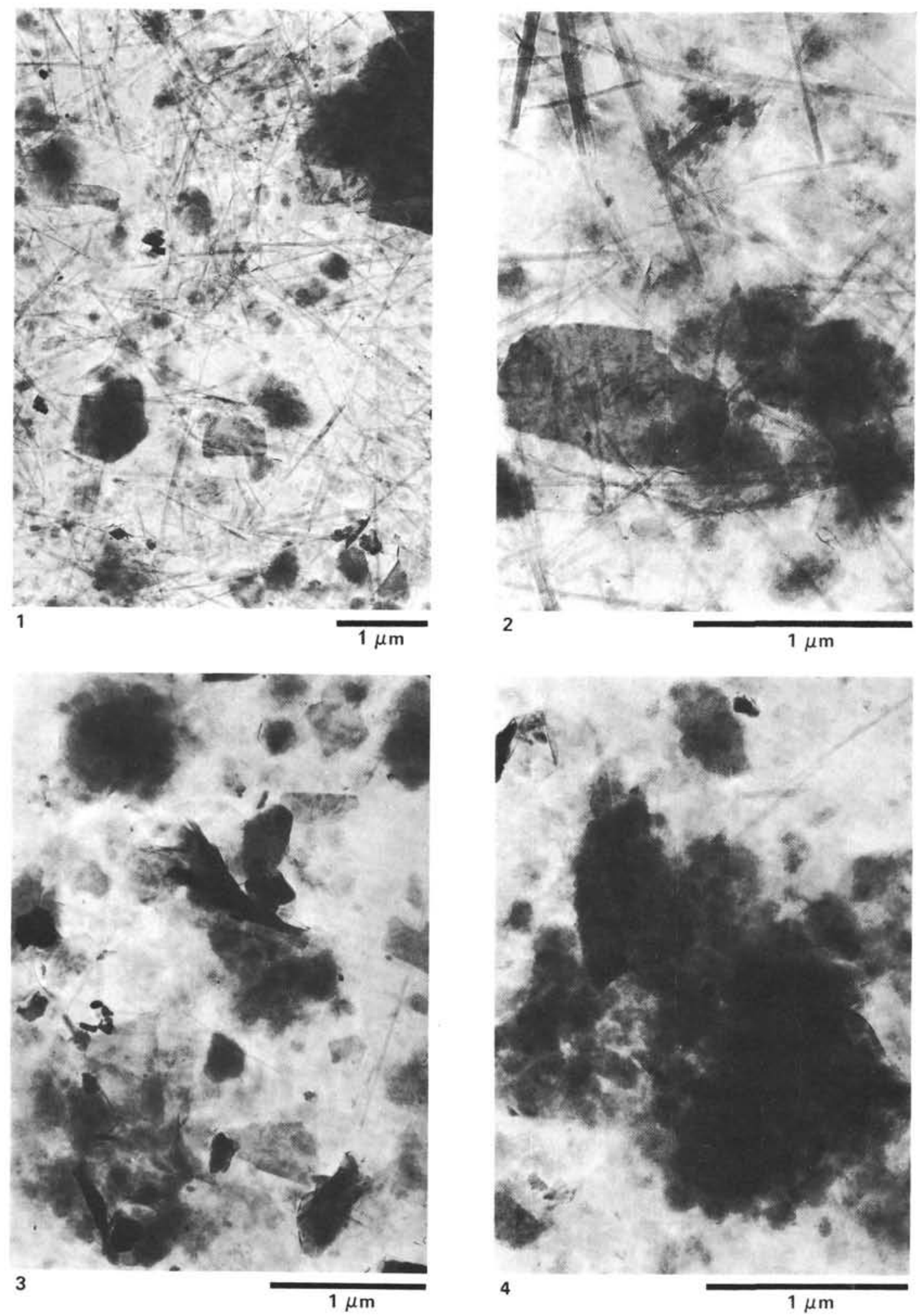

Plate 2. Electron micrographs. 1,2. Palygorskite-rich assemblage. Sample 576B-8-3, $82 \mathrm{~cm}$, upper Cretaceous, dark brown pelagic clay. Abundant palygorskite, as isolated fibers or bundles, often broken, dispersed among fleecy smectite and well-shaped illite. 3,4. Smectite-rich assemblage. Sample 578-15-4, $33 \mathrm{~cm}$, early Cenozoic (?), brown pelagic clay. Abundant fleecy and cloudy smectite, associated with low amounts of illite and palygorskite. 